E ISSN: 2622-223X

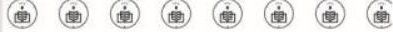

P ISSN: 2598-7607

Vol. II No. 01 (Maret - September) 2017

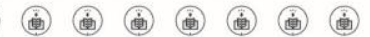

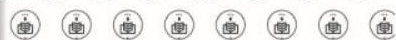

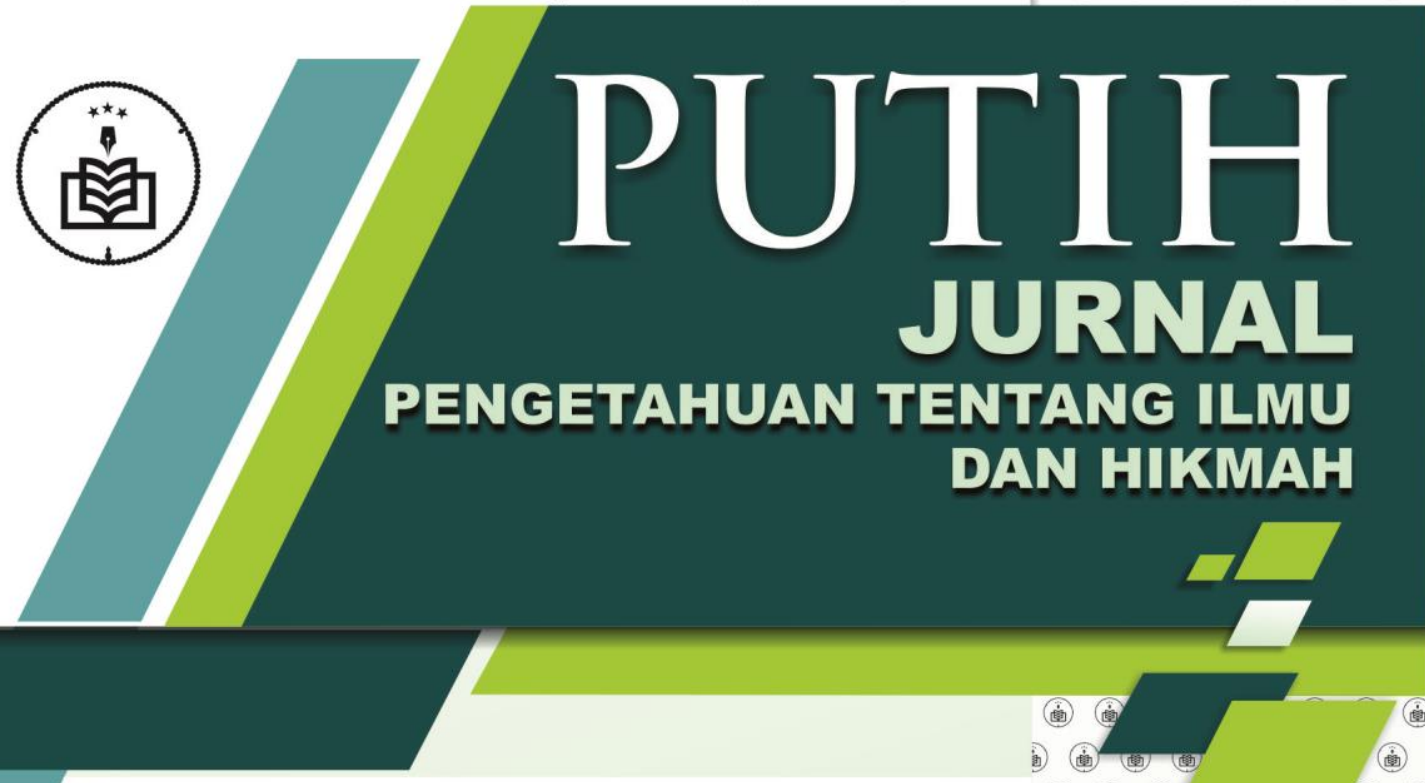

\section{HAKIKAT DOA}

Muhammad Husein Basofi 1-22

- MANAQIB SYEIKH ABDUL QADIR SEBAGAI MEDIA SULUK Durrotun Hasanah 23-42

- RELASI ANTARA AKAL DENGAN HATI PERSPEKTIF KH. ACHMAD ASRORI AL-ISHAQY Irwanto 43-64

- RELEVANSI AJARAN BUDHA DAN TASAWUF Mohammad Arista 65-100

- TERAPI SPIRITUAL MELALUI TAZKIYAH AL-QALB PERSPEKTIF ULAMA SHUFIYYAH

Anas Fajriansyah 101-122 (19i) (1) (19)

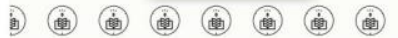

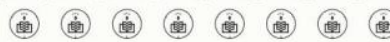

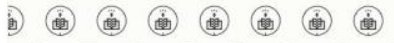

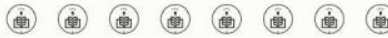

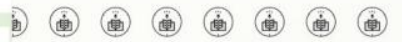

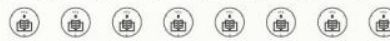

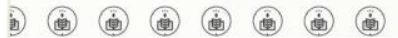

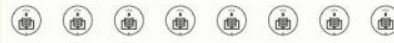
ib) (iii) (iii) (ii) (ii) (iii) (iii) (iit)

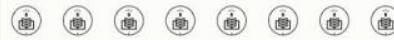

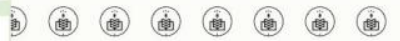

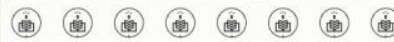

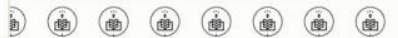

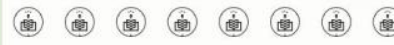

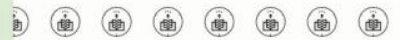

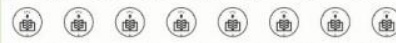

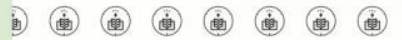

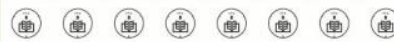
diterbitkan :

MA'HAD ALY

PONDOK PESANTREN ASSALAFI AL FITHRAH Surabaya 2017

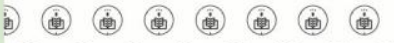

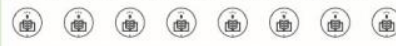
ib) (ii) (ii) (ii) (ii) (ii) (ii) (iii)

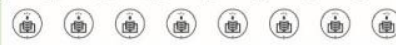
ib) (ii) (iii) (ii) (ii) (ii) (ii) (ii)

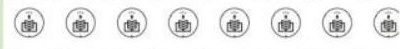

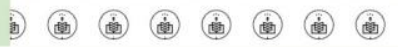




\section{REDAKTUR PUTIH \\ JURNAL PENGETAHUAN TENTANG ILMU DAN HIKMAH}

Ijin terbit

SK. Mudir Ma'had Aly No. 18/MAy-PAF/II/2017/SK

PENGARAH

Muhammad Musyafa'

Abdur Rosyid

Ahmad Syathori

Fathur Rozi

PIMPINAN REDAKSI

Fathul Haris

DEWAN EDITOR

Achmad Imam Bashori

ANGGOTA

Mustaqim

Samsul Arifin

Abdul Hadi

Alamat Penyunting dan Surat Menyurat :

Jl. Kedinding Lor 99 Surabaya

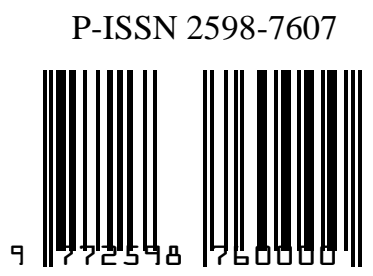

E-ISSN: 2622-223X

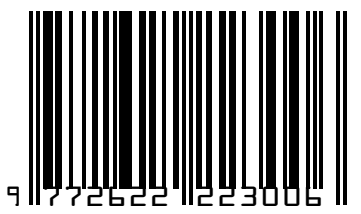

diterbitkan

MA'HAD ALY

PONDOK PESANTREN ASSALAFI AL FITHRAH

Surabaya 


\section{DAFTAR ISI}

DAFTAR ISI

— PEDOMAN TRANSLITERASI

ם HAKIKAT DOA

Muhammad Husein Basofi 1-22

— MANAQIB SYEIKH ABDUL QADIR SEBAGAI MEDIA SULUK

Durrotun Hasanah 23-42

RELASI ANTARA AKAL DENGAN HATI PERSPEKTIF KH. ACHMAD ASRORI AL-ISHAQY

Irwanto 43-64

- RELEVANSI AJARAN BUDHA DAN TASAWUF Mohammad Arista 65-100

TERAPI SPIRITUAL MELALUI TAZKIYAH AL-QALB PERSPEKTIF ULAMA SHUFIYYAH

Anas Fajriansyah 101-122 


\section{PEDOMAN TRANSLITERASI}

Berikut ini adalah skema transliterasi Arab-Indonesia yang ditetapkan dalam penulisan jurnal ini:

\begin{tabular}{|c|c|c|c|c|}
\hline $\mathrm{NO}$ & ARAB & INDONESIA & ARAB & INDONESIA \\
\hline 1 & 1 & 6 & b & t\} \\
\hline 2 & بب & B & ظ & $\mathrm{Z}\{$ \\
\hline 3 & ت & $\mathrm{T}$ & $\varepsilon$ & 6 \\
\hline 4 & ث & $\mathrm{Th}$ & $\dot{\varepsilon}$ & $\mathrm{gh}$ \\
\hline 5 & ج & $\mathrm{J}$ & ف & $\mathrm{F}$ \\
\hline 6 & $\tau$ & $\mathrm{h}\{$ & ق & Q \\
\hline 7 & $\dot{\tau}$ & $\mathrm{Kh}$ & 5) & $\mathrm{K}$ \\
\hline 8 & د & D & J & $\mathrm{L}$ \\
\hline 9 & j & $\mathrm{Dh}$ & 5 & $\mathrm{M}$ \\
\hline 10 & $\jmath$ & $\mathrm{R}$ & ن ن & $\mathrm{N}$ \\
\hline 11 & j & $\mathrm{Z}$ & 9 & W \\
\hline 12 & س & $S$ & $d$ & $\mathrm{H}$ \\
\hline 13 & ش & $\mathrm{Sh}$ & $s$ & , \\
\hline 14 & ص & $s\{$ & ي & $\mathrm{y}$ \\
\hline 15 & ض & $\mathrm{d}\{$ & & \\
\hline
\end{tabular}

Untuk menunjukkan bunyi hidup panjang (madd) dengan cara menuliskan coretan horizontal di atas huruf a, i>dan $u>($ ) $116)$. 


\title{
RELEVANSI AJARAN BUDHA DAN TASAWUF
}

\author{
Oleh: \\ Mohammad Arista \\ Email: Ariestaaries89@yahoo.com
}

Ma'hadAly Al Fithrah

\begin{abstract}
ABSTRAK
Tasawuf ibaratnya adalah ruh dari sebuah agama khusunya agama islam. Dengan tasawuf-lah seseorang dapat mengenali siapa dirinya dan dapat dijadikan sebagai refleksi degredasinya Akhlak seperti zaman sekarang. Tasawuf Dari segi linguistik (kebahasaan) dapat dipahami bahwa tasawuf adalah sikap mental yang selalu memelihara kesucian diri, beribadah, hidup sederhana, rela berkorban untuk kebaikan dan selalu bersikap bijaksana. Sikap jiwa yang demikian itu pada hakikatnya adalah akhlak yang mulia. Tasawuf beresensi pada hidup dan berkembang mulai dari bentuk hidup zuhud (menjauhi kemewahan duniawi) sehingga pada hidup yang modern. Dalam rangka menyucikan jiwa demi tercapainya kesempurnaan dan kebahagiaan hidup tersebut, diperlukan suatu riyadhah (latihan) dari satu tahap ke tahap yang lain yang lebih tinggi.

Jadi, kesempurnaan rohani tidaklah dapat dicapai secara spontan dan sekaligus. Semua sufi sependapat bahwa untuk mencapai tujuan dekat atau berada di hadirat Allah swt. Satu-satunya jalan hanyalah dengan kesucian jiwa. Untuk mencapai tingkat kesempurnaan dan kesucian jiwa diperlukan pendidilan dan latihan mental yang panjang dan bertingkat. Masyarakat modern sering digolongkan sebagai the post industrial society, suatu masyarakat yang telah mencapai tingkat kemakmuaran hidup material yang sedemikian rupa, dengan perangkat teknologi yang serba mekanik dan otomat, manusia modern bukannya semakin mendekati kebahagian hidup, melainkan sebaliknya seringkali
\end{abstract}


dihinggapi rasa cemas, tidak percaya diri dan krisis moral akibat mewahnya gaya hidup marealistik yang didapat., maka pelarian dan pencarian kepada kehidupan lain sebagaimana yang terdapat dalam tasawuf atau mistik adalah hal yang mungkin saja terjadi. Karena di sini mereka akan dapat melepaskan kejenuhan atau mengisi kekosongan jiwa setelah dunia modern mereka gapai dengan terpenuhinya kebutuhan materi yang didapat dengan mudah tersebut.

Dalam kehidupan modern, tasawuf menjadi obat yang mengatasi krisis kerohanian manusia modern yang telah lepas dari pusat dirinya, sehingga ia tidak mengenal lagi siapa dirinya, arti dan tujuan dari hidupnya. Ketidak jelasan atas makna dan tujuan hidup ini membuat penderitaan batin. Mereka lewat spritualitas islam lading kering jadi tersirami air sejuk dan memberikan penyegaran serta mengarahkan hidup lebih baik dan jelas arah tujuannya. Namun menurut sebuah ungkapan ulama mengatakan ilmu tasawuf juga harus beriring imbang dengan syariat begitu sebaliknya, tidak patut hanya bertasawuf tanpa bersyariat terlebih dahulu. Ukuran bersyariat ini. Menurut Syaikh Ahmad Asrori adalah jika kau sudah paha akan hukum yang saat ini dibutuhkan bukan kok harus hatam fathulk muin atau kitab-kitab fiqih yang besar-besar. Maka dari itu tolok ukur bertasawuf ialah jika kau sudah mampu memahami apa itu yang membatalkan wudhu. Inilah yang di sebut sudah bersyariat. Karena memandang tasawuf merupakan unsur inti dari agama islam serta memberikan dampak yang jelas akan kemajuan islam maka Belajar tasawuf yang sangat penting bagi umat Islam bukan pekerjaan yang mudah dilakukan. Dari segi asal-muasal kata saja, sering terjadi pro dan kontra. Belum lagi aplikasi praktisnya untuk menjalani kehidupan ala tasawuf itu sendiri. Ilmu tasawuf bukan hanya teori, melainkan juga praktik. Berbagai pendapat yang sering membingungkan adalah apakah tasawuf itu sesat (mistik dari luar Islam) atau sebuah jalan yang hak sebagai ajaran Islam. Tulisan ini mengajak pembaca untuk bersama-sama meyakinkan bahwa ajaran tasawuf itu murni dari ajaran Islam bukan pengaruh dari luar Islam. Pemikiran dan praktek tasawuf yang dihasilkan dari pemahaman terhadap al-Qur'an dan al-Hadits berbeda dengan pemikiran bebas yang tidak bersumber dari keduanya. Dari sinilah para orientalis mencoba menyusupi 
pemikiran para generasi muda bahwa ajaran tasawuf hanyalah adopsi dari ajaran Budha dan agama lain, dengan cara yang sangat rapi dan terkesan bahwa itu sungguhan mereka juga meneragkan berbagai dalil yang dibua-buat untuk mendukung rencana akbar ini.

Kata kunci: Budha pun tasawuf "Menyanggah para penentang Taswuf" 


\section{PENDAHULUAN}

Di era modern ini kemajuan telah merambah dalam berbagai aspek kehidupan manusia, baik dalam sosial, budaya dan politik, sehingga mengharuskan individu untuk beradaptasi terhadap perubahanperubahan yang terjadi secara cepat dan pasti.Dalam aspek spiritual, masyarakat modern senantiasa terbuai dalam situasi keglamoran, mendewakan ilmu pengetahuan dan teknologi dan mengesampingkan urusan agama. Mereka beranggapan bahwa ilmu pengetahuan dan teknologi akan mampu meningkatkan taraf kehidupan. Padahal, tidak selamanya seperti yang diharapkan, karena dibidang teknologi yang berkembang pada masyarakat modern akan memberikan dan dampak kehidupan manusia, yaitu dapat memberikan dampak positif dan pada sisi lain, juga dapat menimbulkan dampak negatif. ${ }^{107}$

Kemajuan di bidang teknologi pada zaman modern ini telah membawa manusia ke dalam dua sisi, yaitu bisa memberi nilai tambah (positif) tapi pada sisi lain dapat mengurangi (negative) . efek positifnya tentu saja akan meningkatkan keragaman budaya melalui penyediaan informasi yang menyeluruh sehingga memberikan orang kesempatan untuk mengembangkan kecakapan baru dan meningkatkan produksi. Sedangakan efek negative nya kemajuan teknologi akan berbahaya jika berada di tangan orang yang secara mental dan keyakinan agama belum siap. Mereka dapat menyalahgunakan teknologi kontrasepsi dapat menyebabkan orang mudah dapat melakukan hubungan seksual tanpa harus ikut hamil atau berdosa. Jaringan jaringan peredaran, obat obat terlarang, tukar menukar informasi, penyaluran data data film yang berbau pornografi di bidang teknologi komunikasi seperti computer, faximile, internete, dan sebagainya akan semakin intensif pelaksanaannya. Hal tersebut di atas adalah gambaran masyarakat modern yang obsesi keduniaannya tampak lebih dominan ketimbang spiritual. Kemajuan teknologi sains dan segala hal yang bersifat duniawi jarang disertai dengan nilai spiritual.

Tasawuf berusaha menampilkan visi keagamaan yang otentik, yang mengarahkan diri untuk melampaui kedirian dan sifat egois,

${ }^{107}$ Tim penyusun MKD, Akhlak tasawuf, (Surabaya:iain sa press,2011),353 
tasawuf adalah sebuah visi yang tepat dalam menafsirkan dunia, serta alam lain di luar dunia ini yang mungkin ada dan melingkupi seluruh realitas. Selain itu, tasawuf juga sebuah visi tentang suatu tatanan ideal masyarakat. Dengan demikian, tasawuf adalah sebuah komitmen yang lebih besar dari pada sekedar pemuasan kepentingan egois pribadi dan spritualitas pribadi semata, sekaligus sebuah obsesi yang lebih tinggi dari pada sekedar pemahaman hidup di dunia yang bersifat materi.

Masyarakat modern adalah masyarakat yang cenderung menjadi sekuler, hanya mementingkan kehidupan duniawi, telah secara signifikan menyingkirkan mereka dari segala aspek spritualialitas, akibatnya mereka hidup secara terisolir dari dunia lain yang bersifat non fisik, yang di yakini adanya oleh para sufi. Mereka menolak segala dunia non fisik seperti dunia imajinal atau spiritual sehingga terputus hubungan dengan segala realitas yang lebih tinggi dari pada entitas entitas fisik. Bagi mereka, kehidupan di mulai di dunia ini dan berakhir juga di dunia ini, tanpa tahu dari mana ia berasal dan hendak kemana setelah dia pergi. Akibatnya, mereka hanya berkutat di satu dunia ini saja, sekan mereka tidak pernah punya asal dan tempat kembali. ${ }^{108}$

Keterputusan spiritual yang seperti itu membuat manusia modern juga kehilangan kontak mereka dengan tuhan, sumber dari segala yang ada. Sementara bagi para sufi, tuhan adalah alfa dan omega, asal dan tempat kembali. Bagi banyak orang modern tuhan hanyalah di pandang sebagai penghalang bagi penyelenggaraan diri merekam dan kebebasan menyertainya. ${ }^{109}$ Akibat dari keputus asaan ini, manusia modern mengalami gelisah dan sebangsanyam karena mereka tidak lagi mengarahkan jiwanya kepada tuhan yang maha esa yang menjadi sumber ketauhidan manusia tetapi bertumpu kepada beraneka benda benda fisik, yang selalu timbul tenggelam, oleh karena itu benda benda tersebut tidak pernah memberi kepuasan dan ketenangan kepada mereka.Dan dengan berkembangnya ilmu pengetahuan dan teknologi ini juga akan berbahaya jika berada di tangan orang yang secara mental dan

\footnotetext{
${ }^{108}$ Mulyadi kartanegara, menyelami lubuk tasawuf, (Jakarta: penerbit erlangga,2006),264

${ }^{109}$ Ibid,269
} 
keyakinan agamnya belum siap. Mereka dapat menyalah gunakan teknologi dengan tujuan tujuan yang menghawatirkan. Mereka belum memahami bahwa iptek juga merupakan sumber dari berbagai ilmu pengetahuan yang bersifat positif yang bisa mereka manfaatkan isinya.

Dalam mempelajari ilmu tasawuf kita menemukan banyak teori yang berkaitan dengan asal usul ajaran tasawuf. Di antara teori yang satu dengan teori yang lain telah menimbulkan pro dan kontra, sehingga menimbulkan adanya keraguan dan kecaman terutama bagi kalangan yang anti terhadap praktek ajaran tasawuf. Para tokoh muslim (yang simpati dan menekuni ajaran tasawuf) mengatakan, bahwa asal usul tasawuf berasal murni dari ajaran Islam, sementara tokoh-tokoh di luar Islam berpendapat bahwa ajaran tasawuf bukan murni dari ajaran Islam melainkan pengaruh dari ajaran dan pemikiran di luar Islam. Terlepas dari berbagai macam teori yang ada, tulisan ini mencoba merangkum berbagai pendapat yang ditulis oleh pengkaji tasawuf dan selanjutnya mencoba memberikan suatu kesimpulan, apakah asal usul tasawuf murni bersumber dari ajaran Islam atau bukan dari ajaran Islam? Tulisan berikut ini terlebih dahulu mengemukakan asal kata dari "tasawuf" berikut pengertiannya, kemudian memaparkan teori-teori asal usul tasawuf yang berasal dari unsur Islam dan unsur di luar Islam, dan selanjutnya sanggahan terhadap teori oreintalis tentang asal usul tasawuf.

\section{SEJARAH MUNCULNYA TASAWUF}

Dalam mengajukan teori tentang pengertian tasawuf, baik secara etimologi maupun secara istilah, para ahli berbeda pendapat. Secara etimologi, pengertian tasawuf dapat dilihat menjadi beberapa macam pengertian, diantaranya yaitu:

Pertama, tasawuf berasal dari istilah yang dikonotasikan dengan ahlu suffah, yang berarti sekelompok orang pada masa rasulullah saw. yang hidupnya berdiam di serambi-serambi masjid, mereka mengabdikan hidupnya untuk beribadah kepada Allah swt. ${ }^{110}$ Kata sufi berhubungan dengan kata ahlu suffah, yaitu nama yang diberikan kepada sebagian

${ }^{110}$ Rosihun Anwar, Akhlak Tasawuf,(Bandung: CV Pustaka Setia, 2010),143. 
fakir miskin dikalangan orang-orang islam pada masa awal islam. Mereka adalah diantara orang orang yang tidak punya rumah, maka mereka menempati gubuk yang telah dibangun oleh rasulullah saw. di luar masjid di madinah. ${ }^{111}$ Ahlu suffah, orang orang yang ikut pindah dengan nabi dari mekkah ke madinah, dan karena kehilangan harta berada dalam keadaan miskin dan tidak mempunyai apapun. Mereka tinggal di masjid nabi dan tidur di atas bangku batu dengan memakai pelana sebagai bantal. Pelana tersebut di sebut suffah. Dalam bahasa inggrisnya di sebut saddle cushion. Sungguhpun miskin ahlu suffah berhati baik dan mulia. Sifat tidak mementingkan keduniaan, miskin tapi berhati baik dan mulia itulah sifat sifat kaum sufi.

Kedua, tasawuf berasal dari kata sifa', yang berarti julukan bagi orang orang yang bersih dan suci. Maksudnya bagi orang-orang yang membersihkan dan mensucikan diri di hadapan tuhan Nya. ${ }^{113}$ Segolongan (ahli tasawuf) berkata : bahwa pemberian nama shufiyah karena kesucian hatinya dan kebersihan tingkah lakunya. ${ }^{14}$

Ketiga, istilah tasawuf berasal dari kata shaff. Makna shaff dinisbatkan kepada orang orang yang ketika sholat selalu berada di barisan yang paling depan. ${ }^{115}$ Satu kaum berkata: bahwasanya mereka menamakan shufiyah karena mereka berada pada barisan terdepan di sisi Allah dengan ketinggian cita-cita mereka kepada Nya dan kesungguhan mereka untuk bertemu dengan -Nya, juga ketegaran (ketetapan) hati mereka di sisi Nya.

Keempat, istilah tasawuf dinisbatkan kepada orang orang dari bani shuffah. ${ }^{116}$

Kelima, tasawuf dinisbatkan dengan kata istilah bahasa grik atau yunani, yaitu sufi. Istilah ini disamakan maknanya dengan kata hikmah,

\footnotetext{
${ }^{111}$ Abul Alaa Afify, Tasawuf Islam Dan Terjemahnya, (Iskandariyah:Lajnah AlTa'lif,tt),66.

${ }^{112}$ Harun Nasution, Falsafat Dan Mistisme Dalam Islam,(Jakarta: Bulan

Bintang,1973),57.

${ }^{113}$ Rosihun Anwar, Akhlak Tasawuf ......, 143

${ }^{114}$ Muhammad Amin Nawawi, Al- Ta'aruf Li Madzhabahli Tasawuf, (Kairo:Maktabah Al-Kuliyah Al-Azhariyah.1969),34

${ }^{115}$ Rosihun Anwar, Akhlak Tasawuf....., 143

${ }^{116}$ Rosihun Anwar, Ahklak Tasawuf ....,143
} 
yang berarti kebijaksanaan. ${ }^{117}$ Kata shopos dalam bahasa yunani menunjukkan kondisi jiwa yang senantiasa cenderung kepada kebenaran. ${ }^{118}$

Keenam, tasawuf berasal dari kata shufiyah, yaitu sebangsa buahbuahan kecil yang berbulu dan banyak tumbuh di padang pasir di tanah arab. Hal ini dilihat dari pakaian kaum sufi yang berbulu- bulu seperti buah itu pula, dalam kesederhanaannya. ${ }^{1}$

Ketujuh, tasawuf berasal dari kata sufi, yang berarti bulu domba atau wol. ${ }^{120}$ Perkataan yang mengatakan bahwa kata tersebut dari kata shufi (bulu atau wol) apabila memakai baju (yang demikian), sebagaimana dikatakan dia berpakaian kemeja apabila ia memakai kemeja. $^{121}$

Kain wol yang dipakai kaum sufi adalah kain wol yang kasar bukan kain wol yang halus seperti sekarang. Memakai kain wol kasar diwaktu itu adalah symbol kesederhanaan dan kemiskinan. Lawannya ialah memakai sutra,oleh orang-orang yang mewah hidupnya di kalangan pemerintahan. Kaum sufi sebagai golongan yang hidup sederhana dan dalam keadaan miskin, tetapi berhati suci dan mulia, menjauhi pemakaian sutra dan sebagai gantinya memakai wol kasar. ${ }^{122}$

Pakaian ini menggambarkan bahwa mereka adalah orang yang sangat sederhana yang tidak menampilkan diri dengan pakaian-pakaian yang bagus,halus, dan mahal. Hal ini terlihat dari kata sufi itu sendiri yang berarti kain wol kasar. Hal ini juga menggambarkan ketidak cederungan mereka kepada kehidupan dunia.

Pengertian tasawuf secara istilah, telah banyak dikonfirmasikan oleh para ahli yang satu sama lain berbeda pendapat sesuai dengan seleranya masing masing.

${ }^{117}$ Muhammad Gholab, Tasawuf Al Muqorin, (Mesir: Maktabah Al-Nahdhah.tt).26-27.

${ }^{118}$ M. Jamil,Akhlak Tasawuf, (Ciputat:Referensi: 2013),32

${ }^{119}$ Rosihun Anwar, Akhlak Tasawuf......144

${ }^{120}$ Ibid., 144.

${ }^{121}$ Al-Qusyairi,Al-Risalah Al-Qusyairiyyah, (Mesir: Musthofa Al-Bab AlHalabi,1959), 138.

${ }^{122}$ Harun Nasution, Falsafat Dan Mistisisme Dalam Islam........ 57-58

${ }^{123}$ M. Jamil,Akhlak Tasawuf ......,32 
Al-Junaidi mengatakan bahwa tasawuf adalah: beserta Allah tanpa adanya penghubung. ${ }^{124} \mathrm{Amir}$ bin usman al-maliki mengatakan bahwa tasawuf adalah : seorang hamba yang setiap waktunya mengambil waktu yang utama. ${ }^{125}$ Kasyf al-zhunun mendefinisikan tasawuf sebagai ilmu yang dengannya dapat diketahui cara manusia sempurna meniti jalan menuju kebahagiaan. ${ }^{126}$ Menurut syeikh abdul qodir isa berkata: tiang penyangga tasawuf adalah penyucian hati dari kotoran materi, dan pondasinya adalah hubungan manusia dengan sang pencipta yang agung, sufi adalah orang yang hati dan interaksinya murni hanya untuk Allah, sehingga Allah memberinya karomah. ${ }^{127}$

Tasawuf itu pikiran penuh dengan konsentrasi satu, hati yang bersandar pada Allah, dan perbuatan yang bersandar pada kitab Allah dan sunnah rasul -Nya, orang sufi itu seperti tanah, setiap kejelekan (kotoran) dilemparkan kepadanya, tapi tanah itu masih tetap membuahkan yang baik. Orang sufi itu seperti bumu yang diinjak oleh orang baik dan orang jelek, atau seperti mendung yang menutupi (mengayomi) segala sesuatu yang ada, dan seperti tetesan air yang menyirami semuanya. ${ }^{128}$ Muhammad amin kurdi mengatakan bahwa tasawuf adalah: suatu ilmu yang dengannya dapat diketahui hal,ihwal, kebaikan dan keburukan jiwa, cara membersihkannya dari yang tercela dan mengisinya dengan sifat-sifat terpuji, cara melakukan suluk dan perjalanan menuju (keridhoan) Allah dan meninggalkan (laranganlarangan -Nya) menuju kepada perintah $-\mathrm{Nya} .{ }^{129} \mathrm{Ahmad}$ al wasi berkata: bahwa tasawuf itu tidak popular pada masa awal islam yakni pada masa shohabat dan tabiin karena pada kurun waktu itu hamper semua umat islam ahli taqwa,wara' dan ahli ibadah. Jaraknya dengan rasulullah saw yang menjalani kehidupan asketis dan sufistik masih relative dekat.

\footnotetext{
${ }^{124}$ Ibid.., 146

${ }^{125} \mathrm{Ibid} . . ., 146$

${ }^{126}$ Khalifah, Kasyf Al-Zhunun Asami,(Ttp: Al-Kutub Wa Al-Funun,Tt),413-414

${ }^{127}$ Abdul Qodir Isa, Hakikat Tasawuf,(Ttp:Penerbit Qisthi Press,2011),6.

${ }^{128}$ Abul Qasim Abdul Karim Hawazin Al-Qusyairi An-Naisaburi, Risalah AL-

Qusyairiyah, (Jakarta: Pustaka Amani,2007),417.

${ }_{129}$ Muhammad Amin AL-Kurdi, Tanwir Al-Qulub Fi Muamalah 'Alam Al-Ghuyub, (Surabaya: Pen Bungkul Indah,Tt),406
} 
Sehingga, tidak diperlukan pembahasan secara khusus. Tidak perlu diragukan juga nilai nilai asketisme di masa nabi Muhammad saw. dan sahabat sampai pada tabiin. Banyak ilmu keislaman yang dikembangkan justru ketika sudah jauh dari masa kehidupan rasulullah saw. tradisi penulisan alquran misalnya, populer setelah rasulullah wafat. ${ }^{130}$

Dari segi linguistik (kebahasaan) dapat dipahami bahwa tasawuf adalah sikap mental yang selalu memelihara kesucian diri, beribadah, hidup sederhana, rela berkorban untuk kebaikan dan selalu bersikap bijaksana. Sikap jiwa yang demikian itu pada hakikatnya adalah akhlak yang mulia. ${ }^{131}$ Tasawuf beresensi pada hidup dan berkembang mulai dari bentuk hidup zuhud (menjauhi kemewahan duniawi) sehingga pada hidup yang modern.

Dalam rangka menyucikan jiwa demi tercapainya kesempurnaan dan kebahagiaan hidup tersebut, diperlukan suatu riyadhah (latihan) dari satu tahap ke tahap yang lain yang lebih tinggi. Jadi, kesempurnaan rohani tidaklah dapat dicapai secara spontan dan sekaligus. Semua sufi sependapat bahwa untuk mencapai tujuan dekat atau berada di hadirat Allah swt. Satu-satunya jalan hanyalah dengan kesucian jiwa. Untuk mencapai tingkat kesempurnaan dan kesucian jiwa diperlukan pendidilan dan latihan mental yang panjang dan bertingkat. ${ }^{132}$

Jika ditelaah, kehidupan manusia dapat dikatakan bahwa adanya kecenderungan manusia untuk kembali mencari nilai ilahiyah merupakan bukti manusia bahwa manusia pada dasarnya makhluk rohani selain sebagai makhluk jasmani. Sebagai makhluk jasmani, manusia membutuhkan hal-hal yang bersifat materi, namun sebagai makhlauk rohani mereka membutuhkan hal-hal yang bersifat immateri atau rohani. Sesuai dengan ajaran tasawuf yang lebih menekankan pada aspek rohani, maka mausia itu pada dasarnya cenderung bertasawuf. Dengan kata lain, bertasawuf merupakn fitrah manusia. Dari adanya unsur rohani pada manusia inilah dikatakan urgensinya mempelajari ilmu tasawuf.Oleh karena kecenderungan manusia itu selalu ingin berbuat

\footnotetext{
${ }^{130}$ Ibid., 406

${ }^{131}$ Harun Nasution, Falsafat Dan Mistisme Dalam Islam, (Jakarta: Bulan Bintang,1983),56-57.

${ }^{132}$ Ibid,. 28
} 
baik sesuai dengan nilai ketuhanan, maka segala perbuatan yang menyimpang daripadanya merupakan penyimpangan dan melawan fithrahnya. Pada dasarnya tujuan akhir manusia adalah mengikuti lingkaran rohaniyah dengan Allah swt. Sebagai hubungan yang selamanya benar.

Pendahuluan Dalam mempelajari ilmu tasawuf kita menemukan banyak teori yang berkaitan dengan asal usul ajaran tasawuf. Di antara teori yang satu dengan teori yang lain telah menimbulkan pro dan kontra, sehingga menimbulkan adanya keraguan dan kecaman terutama bagi kalangan yang anti terhadap praktek ajaran tasawuf. Para tokoh muslim (yang simpati dan menekuni ajaran tasawuf) mengatakan, bahwa asal usul tasawuf berasal murni dari ajaran Islam, sementara tokohtokoh di luar Islam berpendapat bahwa ajaran tasawuf bukan murni dari ajaran Islam melainkan pengaruh dari ajaran dan pemikiran di luar Islam. Terlepas dari berbagai macam teori yang ada, tulisan ini mencoba merangkum berbagai pendapat yang ditulis oleh pengkaji tasawuf dan selanjutnya mencoba memberikan suatu kesimpulan, apakah asal usul tasawuf murni bersumber dari ajaran Islam atau bukan dari ajaran Islam? Tulisan berikut ini terlebih dahulu mengemukakan asal kata dari "tasawuf" berikut pengertiannya, kemudian memaparkan teori-teori asal usul tasawuf yang berasal dari unsur Islam dan unsur di luar Islam, dan selanjutnya sanggahan terhadap teori oreintalis tentang asal usul tasawuf.

Asal usul Kata Tasawuf. Menurut bahasa Para ulama tasawuf berbeda pendapat tentang asal usul penggunaan kata tasawuf. Dari berbagai sumber rujukan buku-buku tasawuf, paling tidak ada lima pendapat tentang asal kata dari tasawuf. Pertama, kata tasawuf dinisbahkan kepada perkataan ahlshuffah, yaitu nama yang diberikan kepada sebagian fakir miskin di kalangan orang Islam pada masa awal Islam. Mereka adalah diantara orang-orang yang tidak punya rumah, maka menempati gubuk yang telah dibangun Rasulullah di luar masjid di Madinah. ${ }^{133}$

${ }^{133}$ Abul Alaa Afify, Fi al Tashawwuf al Islam wa Tarikhikhi, (Iskandariyah: Lajnah al Ta'lif wa al-Tarjamah wa al Nasyr, tt), 66. 
Ahlu Al-Shuffah adalah sebuah komunitas yang memiliki ciri yang menyibukkan diri dengan kegiatan ibadah. Mereka meninggalkan kehidupan dunia dan memilih pola hidup zuhud. Mereka tinggal di masjid Nabi dan tidur di atas bangku batu dengan memakai pelana (sofa), mereka miskin tetapi berhati mulia. Para sahabat nabi hasil produk shuffah ini antara lain Abu Darda', Abu Dzar al Ghifari dan Abu Hurairah. ${ }^{134}$ Kedua, ada pendapat yang mengatakan tasawuf berasal dari kata shuf, yang berarti bulu domba. Berasal dari kata shuf karena orangorang ahli ibadah dan zahid pada masa dahulu menggunakan pakaian sederhana terbuat dari bulu domba. Dalam sejarah tasawuf banyak kita dapati cerita bahwa ketika seseorang ingin memasuki jalan kedekatan pada Allah mereka meninggalkan pakaian mewah yang biasa dipakainya dan diganti dengan kain wol kasar yang ditenun sederhana. Tradisi pakaian sederhana dan compang camping ini dengan tujuan agar para ahli ibadah tidak timbul rasa riya', ujub atau sombong. ${ }^{135}$ Ketiga, tasawuf berasal dari kata shofi, yang berari orang suci atau orang-orang yang mensucikan dirinya dari hal-hal yang bersifat keduniaan. ${ }^{136}$ Mereka memiliki ciri-ciri khusus dalam aktifitas dan ibadah mereka atas dasar kesucian hati dan untuk pembersihan jiwa dalam rangka mendekatkan diri kepada Allah. Mereka adalah orang yang selalu memelihara dirinya dari berbuat dosa dan maksiat. Pendapat yang keempat mengatakan bahwa tasawuf berasal dari kata shaf, yaitu menggambarkan orangorang yang selalu berada di barisan depan dalam beribadah kepada Allah dan dalam melaksanakan kebajikan. ${ }^{137}$ Sementara pendapat yang lain mengatakan bahwa tasawuf bukan berasal dari bahasa Arab melainkan bahasa Yunani, yaitu sophia, yang artinya hikmah atau filsafat. ${ }^{138}$ Menisbatkan dengan kata sophia karena jalan yang ditempuh oleh para ahli ibadah memiliki kesamaan dengan cara yang ditempuh oleh para filosof. Mereka sama-sama mencari kebenaran yang dari

\footnotetext{
${ }^{134}$ Muhammad Sholikhin, Tradisi Sufi dari Nabi, (Cakrawala: Yogyakarta), 2009, 19 ${ }^{135}$ Ibid., 21

${ }^{136}$ Khoiri, Alwan. AkhlakTasawuf, (Yogyakarta: Pokja Akademik UIN Sunan Kalijaga, 2005), 29.

${ }^{137}$ Yasir Nasution, Cakrawala Tasawuf (Jakarta: Putra Grafika, 2007), 3

${ }^{138}$ Alwan Khoiri,Akhlak 30.
} 
keraguan dan ketidakpuasan jiwa. Contoh ini pernah dialami oleh Iman al Ghazali dalam mengarungi dunia tasawuf. Masih banyak pendapat lain yang menghubungkan kata tasawuf dengan perkataan-perkataan lain yang dapat dirujuk dalam buku-buku tasawuf. Yang jelas dari segi bahasa terlepas dari berbagai pendapat yang ada, dapat dipahami bahwa tasawuf adalah sikap mental yang selalu memelihara kesucian diri, beribadah, hidup sederhana, rela berkorban untuk kebaikan dan selalu bijaksana serta mengutamakan kebajikan.

Menurut Istilah Selanjutnya tasawuf dari aspek terminologis (istilah) juga didefinisikan secara beragam, dan dari berbagai sudut pandang. Hal ini dikarenakan bebeda cara memandang aktifitas para kaum sufi. Ma'ruf al Karkhi mendefinisikan tasawuf adalah "mengambil hakikat dan meninggalkan yang ada di tangan mahkluk". ${ }^{139}$ Abu Bakar Al Kattani mengatakan tasawuf adalah" budi pekerti. Barangsiapa yang memberikan bekal budi pekerti atasmu, berarti ia memberikan bekal bagimu atas dirimu dalam tasawuf". ${ }^{140}$ Selanjutnya Muhammad Amin Kurdi mendefinisikan tasawuf adalah "suatu yang dengannya diketahui hal ihwal kebaikan dan keburukan jiwa, cara membersihkannya dari yang tercela dan mengisinya dengan sifat-sifat terpuji, cara melaksanakan suluk dan perjalanan menuju keridhaan Allah dan meninggalkan larangannya". ${ }^{41}$ Dari kajian sudut bahasa maupun istilah sebagaimana dijelaskan di atas, menurut Nicholson, bahwa masalah yang berkaitandengan sufismeadalah sesuatu yang tidak dapat didefinisikan secara jelas dan terang, bahkan semakin banyak didefinisikan maka semakin jauh dari makna dan tujuan. ${ }^{142} \mathrm{Hal}$ ini biasa terjadi karena hasil pengalaman sufistik tergantung pada pengamalan masing-masing tokoh sufi. Namun, menurut Abuddin Nata, bahwa walaupun setaip para tokoh sufi berbeda dalam merumuskan arti

${ }^{139}$ AS-Suhrawardi, Awarif al-Ma,rifKamisy Ihya' 'Ulum al-Din(Singapura:, Mar'I,tt), 313.

${ }^{140}$ al-Ghazali, Ihya' 'Ulum ad-Din (Semarang: Maktabah Usaha Keluarga,tt), 376.

${ }^{141}$ Amin al-Kurdi, Tanwir al-Qulub fi Mu'amalah 'Alam al-Ghuyub (Surabaya: Bungkul Indahtt), 406.

${ }^{142}$ Reynold Nicholson, Jalaluddin Rumi, Ajaran dan Pengalaman Sufi (Jakarta: Pustaka Firdaus, 1993), 23. 
tasawuf tapi pada intinya adalah sama, bahwa tasawuf adalah upaya melatih jiwa dengan berbagai kegiatan yang dapat membebaskan dirinya dari pengaruh kehidupan dunia, sehingga tercermin akhlak yang mulia dan dekat dengan Allah. Atau dengan kata lain tasawuf adalah bidang kegiatan yang berhubungan dengan pembinaan mental rohaniah agar selalu dekat dan bersama Allah. ${ }^{143}$ Dari kesimpulan ini maka kemudian melahirkan beberapa teori tentang asal usul ajaran tasawuf, apakah ajaran-ajaran tentang pembersihan jiwa itu murni dari Islam atau justru pengaruh unsur lain di luar Islam. Maka untuk memaknai tujuan dan hakekat tasawuf dalam Islam, kita harus mengkaji pendapat-pendapat lain tentang teori asal usul ajaran tasawuf, sebab dari kalangan orientalis Barat masih membuat kesimpulan bahwa ajaran-ajaran tasawuf dalam Islam, bukan hasil ajaran murni dari ajaran Islam, melainkan pengaruh dari ajaran luar Islam.

Teori Asal Usul Ajaran Dari beberap buku (kajian) tentang asal usul tasawuf, biasanya kita menjumpai pendapat atau teori-teori yang berkaitan dengan sumber-sumber yang membentuk tasawuf. Secara garis besar dapat disimpulkan bahwa ada dua teori yang berpengaruh dalam membentuk tasawuf, yaitu teori yang berasal dari ajaran atau unsur Islam, dan teori yang berasal dari ajaran atau unsur lain di luar Islam. Para orientalis Barat mengatakan bahwa tasawuf bukan murni dari ajaran Islam, sementara para tokoh sufi mengatakan bahwa tasawuf merupakan inti ajaran dari Islam.

Unsur Islam Para tokoh sufi dan juga termasuk dari kalangan cendikian muslim memberikan pendapat bahwa sumber utama ajaran tasawaf adalah bersumber dari al-Qur'an dan al-Hadits. Al-Qur'an adalah kitab yang di dalam ditemukan sejumlah ayat yang berbicara tentang inti ajaran tasawuf. Ajaran-ajaran tentang khauf, raja', taubat, zuhud, tawakal,syukur, shabar, ridha, fana, cinta, rindu, ikhlas, ketenangan dan sebagainya secara jelas diterangkan dalam al-Qur'an. ${ }^{144}$ Antara lain tentang mahabbah (cinta) terdapat dalam surat al-Maidah ayat 54, tentang taubat terdapat dalam surat al-Tahrim ayat 8 , tentang

${ }^{143}$ Abuddin Nata, Akhlak Tasawuf(Jakarta: PT.Raja Grafindo Persada, 2009), 181 ${ }^{144}$ Yasir Nasution, . . . 1014 Abuddin Nata, . . 181 
tawakal terdapat dalam surat at-Tholaq ayat 3, tentang syukur terdapat dalam surat Ibrahim ayat 7 , tentang shabar terdapat dalam surat alMukmin ayat 55, tentang ridha terdapat dalam surat alMaidah ayat 119 , dan sebagainya. ${ }^{145}$ Sejalan dengan apa yang dikatakan dalam al-Qur'an, bahwa al-Hadits juga banyak berbicara tentang kehidupan rohaniah sebagaimana yang ditekuni oleh kaum sufi setelah Rasulullah. Dua hadits populer yang diriwayatkan oleh Bukhari dan Muslim : "Sembahlah Allah seolah-olah engkau melihat-Nya, maka apabila engkau tidak melihat-Nya, maka Ia pasti melihatmu" dan juga sebuah hadits yang mengatakan: "Siapa yang kenal pada dirinya, niscaya kenal dengan Tuhan-Nya" adalah menjadi landasan yang kuat bahwa ajaranajaran tasawuf tentang masalah rohaniah bersumber dari ajaran Islam. Ayat-ayat dan hadits di atas hanya sebagian dari hal yang berkaiatan dengan ajaran tasawuf.

Dalam hal ini Muhammad Abdullah asy-Syarqowi mengatakan: "awal mula tasawuf ditemukan semangatnya dalam al-Qur'an dan juga ditemukan dalam sabda dan kehidupan Nabi SAW, baik sebelum maupun sesudah diutus menjadi Nabi. Begitu juga awal mula tasawuf juga dapat ditemukan pada masa sahabat Nabi beserta para generasi sesudahnya. ${ }^{146}$ Selanjutnya, AbuNashr As-Siraj al-Thusi mengatakan, bahwa ajaran tasawuf pada dasarnya digali dari al-Qur'an dan as-Sunah, karena amalan para sahabat, menurutnya tentu saja tidak keluar dari ajaran al-Qur'an dan as-Sunnah. Demikian pula menurut Abu Nashr, bahwa para sufi dengan teori-teori mereka tentang akhlak pertamapertama sekali mendasarkan pandangan mereka kepada al-Qur'an dan as-Sunnah (Yasir Nasution, 2007: 18). Selanjutnya di dalam kehidupan Nabi Muhammad SAW juga terdapat banyak petunjuk yang menggambarkan dirinya sebagai seorang sufi. Nabi Muhammad telah melakukan pengasingan diri ke Gua Hira menjelang datangnya wahyu. Dia menjauhi pola hidup kebendaan di mana waktu itu orang Arab menghalalkan segala cara untuk mendapatkan harta. Dikalangan para

\footnotetext{
${ }^{145}$ Abuddin Nata, . . . 181

${ }^{146}$ Muhammad Abdullah Asy-Syarqawi, Sufisme \& Akal, terj. Halid al-Kaf (Bandung: Pustaka Hidayah), 2003, 29
} 
sahabat pun juga kemudian mengikuti pola hidup seperti yang dilakukan oleh Nabi Muhammad SAW. Abu bakar Ash-Shiddiq misalnya berkata: "Aku mendapatkan kemuliaan dalam ketakwaan, kefanaan dalam keagungan dan rendah hati". Demikian pula sahabat-sahabat beliau lainnya seperti Umar bin Khottob, Ustman bin Affan, Ali bin Abi Thalib, Abu Dzar al-Ghiffari, Bilal, Salman al-Farisyi dan Huzaifah alYamani. ${ }^{147}$ Dari berbagai pendapat di atas dapat dipahami, bahwa teori asal usul tasawuf bersumber dari ajaran Islam. Semua praktek dalam kehidupan para tokoh-tokoh sufi dalam membersihkan jiwa mereka untuk mendekatkan diri pada Allah mempunyai dasar-dasar yang kuat baik dalam al-Qur'an maupun as-Sunnah. Teori-teori mereka tentang tahapan-tahapan menuju Allah (maqomat) seperti taubat, syukur, shabar, tawakal, ridha, takwa, zuhud, wara' dan ikhlas, atau pengamalan batin yang mereka alami (ahwal) seperti cinta, rindu, intim, raja dan khauf, kesemuanya itu bersumber dari ajaran Islam.

Unsur di luar Islam Menurut teori Ignas Goldziher, bahwa asal usul tasawuf terutama yang berkaitan dengan ajaran-ajaran yang diajarkan dalamtasawuf merupakan pengaruh dari unsur-unsur di luar Islam. Goldziher mengatakan, bahwa tasawuf sebagai salah satu warisan ajaran dari berbagai agama dan kepercayaan yang mendahului dan bersentuhan dengan Islam. Bahkan berpendapat bahwa beberapa ide alQur'an juga merupakan hasil pengolahan "ideology" agama dan kepercayaan lain. ${ }^{148}$ Unsur agama dan kepercayaan lain selain Islam itu adalah unsur pengaruh dari agama Nashrani, Hindu-Budha, Yunani dan Persia. Pengaruh dari unsur agama Nashrani terlihat pada ajaran tasawuf yang mementingkan kehidupan zuhud dan fakir. Menurut Ignas Goldziher dan juga para Orientalis lainnya mengatakan bahwa kehidupan zuhud dalam ajaran tasawuf adalah pengaruh dari rahib-rahib Kristen. ${ }^{149}$ Begitu pula pola kehidupan fakir yang dilakukan oleh para

${ }^{147}$ Moh. Ghallab, al-Tasawuf al-Muqarin (Kairo: Maktabah al-Nahdah), t.t., 29

${ }^{148}$ Ignas Goldziher, Pengantar Teologi dan Hukum Islam (Jakarta: INIS Jakarta), 1991, 126-128

${ }^{149}$ Harun Nasution, Filsafat dan Mistisisme Dalam Islam (Jakarta: Bulan Bintang), 1973, 57 
sufi adalah merupakan salah satu ajaran yang terdapat dalam Injil. Dalam agama Nashrani diyakini bahwa Isa adalah orang fakir. Di dalam Injil dikatakan bahwa Isa berkata: "Beruntunglah kamu orangorang miskin, karena bagi kamulah kerajaan Alah. Beruntunglah kamu orangorang yang lapar, karena kamu akan kenyang". ${ }^{150}$ Selain Ignas Goldziher, pendapat yang serupa juga dilontarkan Reynold Nicholson. Menurut Nicholson, "Banyak teks Injil dan ungkapan al-Masih (Isa) ternukil dalam biografi para sufi angkatan pertama. Bahkan, sering kali muncul biarawan Kristen yang menjadi guru dan menasehati kepada asketis Muslim. Dan baju dari bulu domba itu juga berasal dari umat Kristen". ${ }^{151}$ Di samping pengaruh dari ajaran Nashrani, Goldziher juga mengatakan, bahwa ajaran tasawuf banyak dipengaruhi oleh ajaran Budha. Dia mengatakan bahwa ada hubungan persamaan antara tokoh Budha Sidharta Gautama dengan tokoh sufi Ibrahim bin Adamyang meninggalkan kemewahan sebagai putra mahkota. Bahkan, Goldziher mengatakan para sufi belajar menggunakan tasbih sebagaimana yang digunakan oleh para pendeta Budha, begitu juga budaya etis, asketis serta abstraksi intelektual adalah pinajaman dari Budhisme. ${ }^{152}$ Ada kesamaan paham fana dalam tasawuf dengan nirwana dalam agama Budha. Begitu juga ada kesamaan cara ibadah dan mujahadah dalam ajaran tasawuf dengan ajaran Hindu. Menurut Harun Nasution, bahwa paham fana hampir sama dengan nirwana dalam agama Budha, dimana agama Budha mengajarkan pemeluknya untuk meninggalkan dunia dan memasuki hidup kontemplatif. Demikian dalam ajaran Hindu ada perintah untuk meninggalkan dunia untuk mencapai persatuan Atman dan Brahman. ${ }^{153}$ Untuk selanjutnya ada juga teori yang mengatakan bahwa tasawuf juga dipengaruhi oleh unsur Yunani. Menurut Abuddin Nata, bahwa metode berfikir filsafat Yunani telah ikut mempengaruhi pola berfikir umat Islam yang ingin berhubungan dengan Tuhan. Hal ini

${ }^{150}$ Abuddin Nata, . . . 18620 Abul al-Wafa' al-Ghanimi al-Taftazani, Madkhal ala al Tashawwuf alIslam, terj. Ahmad Rofi' Ustman, "Sufi Dari Zaman ke Zaman”,

(Bandung: Pustaka): 1985, 25

${ }^{151}$ Reynold Nicholson, . . . 16

${ }^{152}$ Ibid., 17

${ }^{153}$ Harun Nasution, . . . 59 
terlihat dari pemikiran al-Farabi, al-Kindi, Ibn Sina tentang filsafat jiwa. Demikian juga uraian mengenai ajaran tasawuf yang dikemukakan oleh Abu Yazid, al-Hallaj, Ibn Arabi, Suhrawardi dan lain-lain. Menurut Abuddin Nata, ungkapan Neo Platonis :"Kenallah dirimu dengan dirimu" telah diambil sebagai rujukan oleh kaum sufi memperluas makna hadits yang mengatakan: "Siapa yang mengenal dirinya, niscaya dia mengenal Tuhannya". Dari sinilah munculnya teori Hulul, Wihdah Asy-Syuhud dan Wihdah al-Wujud. ${ }^{154}$ Filsafat Emansi Platonis yang mengatakan bahwa wujud alam raya ini memancar dari zat Tuhan Yang Maha Esa. Roh berasal dari Tuhan dan akan kembali kepada Tuhan. Tetapi dengan masuknya ke alam materi, roh menjadi kotor, maka dari itu roh harus dibersihkan. Penyucian roh itu adalah dengan meninggalkan dunia dan mendekati diri dengan Tuhan sedekatdekatnya. Ajaran inilah yang kemudian mempunyai pengaruh terhadap munculnya kaum Zuhud dan sufi dalam Islam. ${ }^{155}$

Kembali pada teori Goldziher, bahwa tasawuf dipengaruhi oleh kepercayaan dan agama di luar ajaran Islam, maka unsur kepercayaan dari Persia dengan sendirimya juga berarti telah ikut serta mempengaruhi tasawuf, karena hubungan politik, pemikiran, social dan sastra antara Arab dan Persia telah terjalin sejak lama. Namun belum ada bukti yang kuat bahwa kehidupan rohani Persia masuk ke tanah Arab. Tetapi memang ada sedikit kesamaan antara istilah zuhud di Arab dengan zuhud menurut agama Manu dan Mazdaq di Persia. Begitu pula konsep ajaran hakekat Muhammad menyerupai paham Harmuz (Tuhan Kebaikan) dalam agama Zarathustra

\section{SANGGAHAN TERHADAP TASAWUF DARI BUDHA}

Sesungguhnya tasawuf Islam sampai dekade terakhir ini masih belum terhitung sebagai lapangan tertutup untuk studi-studi akademi. Maka sejak penghujung abad XIX, tasawuf telah menjadi suatu kajian berbagai studi ilmiah yang tidak terbatas hanya bagi para peneliti muslim, tetapi lebih dari itu para peneliti non muslim pun para

${ }^{154}$ Abuddin Nata, . . . 187

${ }^{155}$ Abuddin Nata, . . . 187 
orientalis-ramai mengkajinya. Tersebutlah nama-nama terkenal dalam literatur tasawuf Islam seperti Annemerie Schimel, FDA. Tholuck, Arberry, A.Hourani, Norman Daniel, Max Horten, RA. Nicholson, Goldziher, R. Hartman, dan lain-lain. Tasawuf Islam sepanjang sejarah telah menyerang pendapat para pemikir dariahli ketimuran dan kebaratan, sekaligus menarik mereka dengan segala kekuatan sehingga mereka tidak mampu menyembunyikan rasa kagum terhadap apa saja yang terkandung dalam tasawuf Islam itu sendiri, baik segi nilai maupun keasliannya. Mereka terpesona dengan sesuatu yang ditunjukkan oleh para sufi sepanjang sejarah mereka, berupa keberanian yang tiada duanya dalam mempertahankan hak dan penyebarannya, serta memerangi kebatilan.

Tak ketinggalan juga apa yang mereka sumbangkan dalam memecahkan problematika metafisika yang timbul di hadapan mereka dan menjadi beban berat bagi para filosof dalam masa yang cukup panjang. Meskipun eksistensi tasawuf dalam Islam semakin meningkat menjadi bagian kajian dari studi keilmuan khususnya dekade kekiniantetapi pendapat yang jelas mengenai berbagai permasalahannya ma-sih sangat minim. Hal ini lebih dipengaruhi oleh faktor-faktor negatif yang dihasilkan dari berbagai studi keilmiahan tersebut, di mana terdapat berbagai pendapat yang kontradiktif baik yang disengaja maupun tidak. Yang jelas kerancuan tersebut bukan dari tasawuf atau para sufi itu sendiri. Kajian tasawuf Islam, lebih spesifik lagi tentang sumber-nya merupakan lahan subur bagi dunia pemikiran. Dalam komunitas pemikir muslim sendiri, sub kajian ini telah melahirkan kontroversi yang tak berujung. Satu contoh, Ibnu Taymiyah seorang pemikir dan ulama besar pada jamannya tak henti-hentinya gencar menyerang tasawuf Islam sekaligus para sufinya. Tetapi beliau juga harus menghadapi serangan balik dari para sufi dan partisipannya.Ilustrasi kontroversi seputar tasawuf ini nampaknya tidak menjadi monopoli bagi para pemikir muslim saja, bahkan mungkin menjadi stimulus akan lahirnya kontroversi yang lebih hebat lagi dalam perspektif kajian orientalis. Telah banyak kajian tasawuf yang keluar dari disket para orientalis. Ada yang terkesan menghantam dan memojokkan, ada pula yang terkesan membela. 
Dalam tulisan ini, penulis ingin memutar kembali 'kaset pergulatan' mereka seputar sumber tasawuf Islam sambil sedikit menyikapinya, dengan menampilkan file tasawuf Islam dari disket Islam yang bebas virus. Kajian Tasawuf Yang Parsial Dalam buku "Mystical Dimensions of Islam", Anne-marie Schimel, seorang orientalis wanita Amerika menulis bahwa guru besar teologi keilmuan FAD. Tholuck adalah orang yang pertama kali -pada tahun 1821- menulis buku yang secara komprehensif mengkaji tasawuf Islam. Bertolak dari situlah maka kajian tasawuf Islam mulai menjamur di Barat, yang pada dekade berikutnya buku Tholuck terkesan kecil. Kalau sedikit dicermati, maka pada dasarnya banyak orientalis Barat yang mengenal tasawuf Islam dari sastra Persi. Arberry telah mendukung sta-temen di atas dengan memberikan satu sampel, bahwa Sir John Malkulum telah menjadikan syair Persi sebagai pijakan dasar kajiannya tentang tasawuf Islam. Karena konsep dari hasil kajian Sir John telah menjadi salah satu referensi kajian ilmiah, maka tak pelak lagi, syair Parsi menjadi sangat populer di kalangan orientalis Jerman dan Perancis.

A. Schimmel menambahkan bahwa syair Al-Hafizh yang pertama kali diterjemahkan telah menjadi cermin dan panduan kaum orientalis (yang berbahasa Inggris) dalam mempersepsikan dan memandang tasawuf Islam. Karena para orientalis tersebut telah memahami tasawuf Islam dari visi syair Persi (seperti Al-Rumi, Jami, Al-Hafizh, AlHayyam) dan tidak dari sumber asli Islam (Al-Quraan dan Al-Sunnah), maka hal ini berdampak logis terhadap lahirnya persepsi mereka yang beragam seputar sumber Tasawuf Islam. Dari kajian yang secara parsial inilah, mereka banyak berasumsi bahwa tasawuf Islam bukan berasal dari sumber ajaran Islam. Mereka mengklaim bahwa tasawuf Islam telah diadopsi dari ajaran Hindu, Budha, Zoroaster, Platonisme, Yahudi dan Kristen. "Saya tidak menemukan seorang orientalis di abad XIX, kecuali mengklaim bahwa tasawuf Islam bersumber dari ajaran ketimuran dan kebaratan", tandas Schimmel.

Menurutnya, paling tidak ada tiga alasan mendasar yang melatarbelakangi kekeliruan analisa mereka. Pertama, para orientalis abad XIX telah mengkaji tasawuf Islam alam perspektif sosiokultural para sufi pada dekade akhir, tetapi tidak memproyeksikan sosio-kultural 
tersebut pada dekade awal -seperti statemen Arberry di atas. Kedua, minimnya kapasitas pengetahuan mereka tentang hakekat Islam. Ketiga, pada abad XIX, Barat terlalu memandang Islam sebagai hina, menakutkan serta gambaran-gambaran negatif lainnya. Di samping itu banyak orientalis yang telah didoktrin oleh pihak gereja untuk mengabdi menjadi agen kristenisasi.

Mereka sengaja menyerang Islam dan membakar semangat bangsa Barat untuk melawan Islam. Johan Vook seorang orientalis Jerman, telah mengakui realita "busuk" seperti itu. Ia menyatakan bahwa pertemuan Gereja Fina telah menyetujui gagasan Bikun Welul, untuk mempelajari bahasa Islam. Keputusan Gereja Fina ini untuk pertama kalinya telah terealisir pada lima universitas besar di Barat. Welul sangat yakin bahwa pada suatu saat nanti, Islam akan runtuh dan ambruk digilas 'buldoser' kristenisasi, dan juga semua manusia akan berakidah Kristen. Nampaknya obsesi Welul inilah yang mengilhami serangan terhadap Islam baik secara materi ataupun serangan pemikiran di saat kolonialisme melanda belahan dunia Islam.

Tasawuf Islam Sebagai Obyek Pengaruh Jika beberapa premis di atas mengisyaratkan dualisme pemikiran dalam kajian Barat, maka dalam sub bagian ini penulis akan menyajikan beberapa argumentasi mereka yang mengklaim tasawuf Islam sebagai ajaran impor. Secara detail mereka telah menganalisa sumber pengaruh Tasawuf Islam dan tidak terbatas dari dimensi ajaran Persi, tapi lebih dari itu semua, dimensi-dimensi ajaran yang ada telah mengalami tusukan analisa mereka.

Baiklah, mari kita ikuti analisa mereka per ajaran yang tetap tidak luput dari pro dan kontra. Untuk itu penulis akan memaparkan secara diskutif. Seorang orientalis Belanda, Dozy, mengklaim bahwa tasawuf Islam berasal dari Persi kuno jauh sebelum diutusnya Nabi Muhammad. Pada saat itu di Persi berkembang pemikiran adanya segala sesuatu yang bertolak dari Tuhan dan semuanya juga akan kembali kepada Tuhan dan juga sebenarnya dunia ini tidak ada secara dzatiyah, yang ada hanyalah Tuhan. Pemikiran-pemikiran inilah yang menurut Dozy telah diadopsi oleh tasawuf Islam. 
Statemen Dozy telah dibuktikan oleh Nicholson dengan hasil kajiannya tentang syakhsiyyah Abu Yazid Al-Busthamy. Abu Yazid adalah seorang tokoh besar dalam dunia tasawuf Islam, dan ternyata beliau adalah termasuk orang Persi kuno. Satu sampel adalah istilah wihdat al-wujud yang sudah populer di kalangan Persi kuno, telah dimasukkan oleh Abu Yazid sebagai istilah baku dalam tasawuf Islam.Tetapi lucunya Nicholson sendiri meragukan kesimpulan tersebut. Terbukti dalam kajian yang sama ia mengatakan bahwa pada dasarnya konsep tasawuf Islam adalah berpijak dari pemikiran Persi atau paling tidak lahir di daratan Persi.

Dari situ kita berhak mengatakan bahwa tasawuf Islam berasal dari ajaran Persi. Tetapi kesimpulan tersebut tidak mutlak benar. Buktinya, memang Ma'ruf Al-Karkhy adalah asli Persi, tetapi konsep alahwal wa al-maqamaat dan serentetan konsep tasawuf lainya adalah muncul dari tokoh-tokoh sesudahnya.Menurut Dr. Abdullah AlSyarqawy, ada enam faktor yang melatarbelakangi klaim para orientalis dalam dimensi ajaran Persi.

Pertama, pengetahuan mereka tentang tasawuf Islam didasari oleh warna Persi kuno. Kedua, banyak pa-ra tokoh sufi berasal dari Persi. Ketiga, adanya bayak kesamaan antara tasawuf Islam dengan ajaran Zoroaster. Keempat, adanya hubungan dan interaksi sosial, budaya, dan peradaban antara masyarakat Persi dan Arab. Kelima, para orientalis dalam kajiannya terlalu apologis ter-hadap ajaran Persi. Keenam, mereka hanya mengkaji secara ilmiah dengan sandaran rasio saja.

Adanya beberapa kesamaan pada konsep tasawuf Islam dengan ajaran Hindu (seperti zuhud, ibadah, tafakkur, dzikir, ma'rifah, fana', dan wihdat al-wujud) telah mengilhami hasil hipotesa para orientalis. Dari pijakan inilah ada beberapa orientalis yang menyatakan bahwa konsep tasawuf Islam telah diadopsi dari konsep ajaran Hindu.Albert FC. mengatakan bahwa dalam tasawuf Islam ada dua unsur pengaruh yang berbeda yaitu unsur Kristiani dan Budha-India. Kedua unsur ini nampak sekali dalam konsep Al-Haritz Al-Hasiby, Abu Yazid Al-Busthamy, Al-Junaid dan Al-Husein bin Mansur Al-Hallaj (yang terkenal dengan wihdat al-wujudnya). Statemen Albert ini telah didukung oleh William John yang telah merasakan adanya korelasi 
antara konsep wihdat al-wujud dalam tasawuf Islam dengan konsep vedanta dalam ajaran Hindu. Tetapi William dibantah oleh Alberry. Ia menyatakan bahwa statemen Willian tersebut telah dibayangi oleh pijakan mendasar oleh syair-syair para sufi Persi saja. Dus, satu hal yang naif sekali karena tanpa menyentuh dasar nash-nash sufi yang paling esensial (literatur tasawuf Islam yang berbahasa Arab, terlebih lagi bahasa Al-Qur'an dan al-Sunnah). Seiring dengan munculnya nada-nada sumbang dari Albert dan William di atas, tak ketinggalan pula Max Horten telah menulis artikel yang sangat banyak.

Tapi artikel-artikel tersebut bagi Arberry dan A. Schimmel bagaikan "kertas bungkusan kacang" yang tak ada nilainya. Mereka mengatakan bahwa para orientalis semisal Max Horten telah mengobral artikel yang banyak hanya sekedar untuk mempertahankan ansumsi utopiannya tentang adanya pengaruh ajaran India dalam tubuh Tasawuf Islam, tetapi mereka 'mandul' dalam memberikan bukti-bukti atas tuduhannya. Dalam bukunya tentang Al-Qusyairy dan risalahnya, Richad Hartman mendukung tuduhan Max Horten. Ia mengatakan bahwa Abu Ali Sindi adalah guru dari Abu Yazid Al-Busthamy. Ia yakin bahwa hal ini merupakan bukti nyata bahwa Tasawuf Islam telah bersumber dari ajaran India.

Asumsi ini pun tak luput dari bantahan. Arberry berkata, "Saya tidak tahu apa dasar Richad Hartman mengatakan bahwa Al-Junaid adalah tokoh yang telah berusaha mengadopsi unsur-unsur asing (seperti Yahudi, Kristen dan Neoplatonisme) dan mengkristalkannya dengan akidah Islam". Maka Arberry sangat menya-yangkannya. Ternyata statemen Hartman kering dari bukti-bukti kuat tentang sosok Al-Junaid. Lebih lanjut dikatakan bahwa Hartman telah menghujum AlJunaid sebelum ia mengkaji secara tuntas tentang sosok Al-Junaid yang sebenarnya. Hartman berkilah lagi bahwa umat Islam sendiri telah mengakui adanya unsur-unsur ajaran India dalam tasawuf mereka. Ia merujuk pada kitab Al-Farid, karangan Abu Raihan Al-Bairuny, yang salah satu statemennya mengatakan bahwa dengan teori Patanjali, para sufi mulai sibuk dengan Tuhannya (istilah sufinya adalah fana' dan baqa'). 
Ia menceritakan pengalaman sufinya Abu Yazid Al-Busthamy. Ketika ditanya, "dengan apa tuan mendapat sesuatu yang tuan dapatkan ?", Al-Busthamy menjawab, "Telah kutinggalkan diriku dariku sebagaimana ular telah tanggal dari kulitnya, lalu kutemui dzatku dimana aku adalah Dia...". Arberry membantah, "Tidaklah cukup kita memvonis bahwa konsep fana' dalam tasawuf Islam adalah adopsi dari Dhyana of Patanjali saja".

Mengakhiri perdebatan ini, penulis ingin mengemukakan komentar Nicholson. Di akhir bukunya "The Idea Of Per-sonality in Sufism", ia menulis bahwa tasawuf Islam secara praktis adalah sama dengan aktifitas keislaman lainnya yang bersandarkan Al-Qur'an dan AlSunnah. Dan suatu hal yang mustahil untuk memahami hakekatnya tanpa mengkaji dulu sumbernya (Al-Qur'an dan Al-Sunnah). DR. Musthafa Helmy menambah-kan bahwa umat Islam belum mengenal ajaran Hindu sebe-lum dikarangnya kitab "Tah-qiq Maa Li al-Hindy" oleh Al-Bayruny. Padahal dia baru me-nyelesaikan tulisannya tersebut pada perempat abad V H.Max Merx, EH. Whinfild dan O'leary adalah para orientalis yang banyak punya andil dalam klaim adanya pengaruh ajaran Yunani dalam Tasawuf Islam. O'leary mengatakan bahwa Tasawuf Islam telah mengadopsi ajaran Yunani sejak abad II H. Sedangkan Whinfield telah mengkompa-rasikan antar ajaran Neoplatonisme tentang sifat-sifat satu dengan sifat-sifat Allah dalam tasawuf Islam.

Ia melihat adanya keselarasan dasar antara keduanya. Nicholson memperkuatnya dengan mengambil bukti penterjemahan buku Aristoteles sekitar tahun 840 M. yang berdampak logis terhadap masuknya faham Neoplatonisme di kalangan umat Islam (terutama para sufi). Dan masih banyak lagi argumen dan bukti yang diajukan oleh Nicholson. Tetapi perlu diingat bahwa ia telah menspesifikasikan kajiannya tentang tasawuf pada abad III H. dan tidak pada abad VI H. seperti yang diduga oleh banyak pengkaji.

Menurutnya ada tiga unsur kesamaan antara tasawuf Islam dengan Neoplatonisme. Pertama, konsep tentang ma'rifat, di mana konsep Neoplatonisme adalah, "Kenalilah dirimu dengan diri-mu". Konsep inilah yang kemudian dikompilasikan para sufi dengan hadits Nabi. 
Kedua, istilah-istilah filsafat seperti makna azali, hakekat, hakekatnya beberapa hakekat, akal pertama, akal substansi dan beberapa istilah lainnya. Istilah-istilah ini telah diambil dari Plato, Aristoteles dan Neoplatonisme yang kemudian diterjemahkan oleh para sufi kedalam konteks "keilahiaan dan hakekat kemu- hammadiyahan". Ketiga, adanya kesamaan kerangka pemikiran dan statemen-statemennya.

Seperti yang telah penulis singgung, pada akhirnya Nicholson juga masih optimis terhadap adanya asas yang paling asli (Al-Qur'an dan AlSunnah) yang mendasari konsep-konsep tasawuf Islam. Sedangkan pengaruh beberapa ajaran dan konsep asing hanya merupakan pengembangan khazanah pemikiran keislaman dan bukan merupakan substansinya. "Kalau memang benar ada pengaruh filsafat Yunani dalam salah satu madzhab tasawuf Islam, boleh jadi hal itu terdapat sejak abad VI H, di saat Ibnu Araby masih hidup," tambah DR. M. Musthafa Helmy.

Di antara para orientalis yang paling bersemangat dalam analisa ini adalah Wensich, Neoldeke, Von Kremer, Julian Baldic, O'leary, Andrae, Asin Palacios, Goldziher dan Gibb. Adalah Von Kremer salah seorang dari mereka yang pertama kali mengkaji sub ini. Ia telah menulis kajian dengan judul "Pengaruh Ahli Zuhud Kristen Dan Ibadah Mereka Terhadap Zuhud Dalam Islam". Menurutnya, ada dua unsur pengaruh yang berbeda dalam tasawuf, yaitu kerahiban Kristen dan kerahiban Budha.

Sedangkan Goldziher telah membedakan antara zuhud dengan tasawuf itu sendiri. Menurutnya, zuhud adalah kuatnya hubungan antara ruh Ilahiah dan madzhab Ahlussunnah, di mana dalam Islam telah berkembang pemikiran "anti dunia dalam" -termasuk zuhud- sehingga lahir istilah-istilah seperti tawakkal, tunduk secara mutlak kepada Allah, hari kiamat, hari kebangkitan, hari perhitungan dan sebagainya.Tetapi setelah itu, menurutnya, Rasulullah telah melarang untuk melampaui batas dalam berzuhud dan meninggalkan dunia. Ia mengistilahkannya dengan peng-ingkaran nyata terhadap zuhud itu sendiri. Ia memberikan sampel beberapa hadits Nabi yang melarang puasa terus-menerus (shaum al-dahr), tidak tidur semalam suntuk dalam ibadah dan lain sebagainya. 
Mendengar pernyataan Goldziher ini, Prof. DR. Al-Taftazany agak geli. Beliau melihat adanya dualisme pemikiran dalam pernyataan Goldziher. Di satu pihak ia yakin bahwa zuhud berasal dari Islam, tapi di pihak lain ia telah menyatakan bahwa Rasulullah dan para ahli zuhud telah mengadopsinya dari ajaran Kristen atau dari Perjanjian Baru. Dengan kata lain, zuhud adalah asli produk Kristen. DR.Al-Taftazaany cukup argumentatif, karena penulis sendiri merasakan adanya subyektifitas dalam kajian Goldziher tersebut. Di samping pengakuannya sendiri akan munculnya zuhud dari Risalah Islamiyah, realitas sepanjang sejarah para zuhud muslim pun cukup menjadi saksi. Dan masih banyak lagi. Mereka telah merangkai dengan sekuat tenaga beberapa argumentasi dan bukti untuk menguatkan persepsi mereka.

DR. Abdurrahman Badawy mengkonklusikannya kedalam lima poin. Pertama, adanya kesamaan pada sebagian fenomena seperti memakai pakaian-pakaian yang sobek, memakai pakaian dari bulu domba. Kedua, adanya persamaan di sebagian pemikiran dan konsep, seperti introspeksi diri (muhasabah al-nafs). Ketiga, adanya kesamaan pada sebagian istilah dan pelafalan. Keempat, dalam kenyataan sejarah telah terjadi integrasi antara umat Islam dengan umat Kristen Arab di berbagai daerah, baik sebelum datang Islam atau sesudah datangnya Islam. Kelima, beberapa statemen yang diriwayatkan oleh para sufi pada masa awal telah dinisbatkan kepada Al Masih. Tak ketinggalan, Arberry sendiri, seorang orientalis, tidak senada dan bahkan menegur statemenstatemen mereka. Ia mengatakan bahwa kebanyakan kaum orientalis kalau menemukan mutiara (baca: nilai positif) dalam Islam sering diklaim berasal dari ajaran di luar Islam, dan nampak sekali adanya kecurangan dan apologi yang membabi buta. Dari kecurangan tersebut bahkan telah berbalik menyerang sebagian di antara mereka sendiri.

Perdebatan sengit yang terjadi antara Max Horten Cs. yang menyatakan unsur Hindu ke dalam tasawuf Islam dengan Arberry dan A. Schimmel, yang sangat agresif membantah dan mematahkan argumentasi mereka, menjadi cukup ironis setelah kita mendengar pernyataan dari pihak Hindu sendiri. Tarachand, salah seorang sejarawan Hindu yang cukup terkenal telah menulis dalam bukunya "Influence of 
Islam on India Culture", bahwa tasawuf Islam lah yang sebenarnya telah mempengaruhi tasawuf Hindu sejak abad I H.

Lebih lanjut ia menyatakan bahwa Islam adalah agama dakwah dan semua pemeluknya adalah para da'i yang menyerukan risalah Islamiah. Dari situlah, berkembang pesat Islam menelusuri pantai barat India yang berdampak logis pada terjadinya integrasi dan pengkristalan nilai-nilai Islam terhadap ajaran Hindu. Kalau dikomparasikan dengan ajaran Kristen, maka Kristen hanya sedikit sekali andilnya dalam mempengaruhi ajaran Hindu. Bahkan, boleh jadi tidak sama sekali. Tasawuf Islam semula diklaim habis-habisan sebagai obyek pengaruh ajaran dari masyriq sampai maghrib, tetapi ternyata klaim tersebut tidak lebih dari sekedar kamuflase untuk menutupi aib mereka. Statemen ini bisa dibuktikan dengan pernyataan Nicholson, bahwa dalam bidang sufisme dan psikologi, Barat telah banyak mengambil dari Islam.

Bidang sufi adalah termasuk yang paling banyak diadopsi oleh Barat. Dalam buku "History of The Arabs", Philip Hitti seorang sejarawan, mengatakan bahwa kitab Ihya 'Ulum al-Dien salah satu kitab tasawuf Islam telah banyak mempengaruhi para pemikir Yahudi dan Kristen pada masa pertengahan. Satu bukti lagi, seperti yang dikatakan Arberry bahwa Raymond Lull dalam beberapa tulisannya telah banyak dipengaruhi oleh analisa sufisme Islam. Dan sejarah pun membuktikan bahwa para tokoh sufisme Kristen seperti Goethe, Dante, ST. Acquinas, serta Echart yang tergabung dalam kelompok Agustus juga telah dipengaruhi oleh sufisme Islam. Lebih lanjut, bukti-bukti ini banyak dikupas oleh Mr. Idris Syah dalam bukunya "The Sufis".

Setelah menelusuri beberapa kajian sumber tasawuf Islam dalam versi orientalis yang penuh dengan pro dan kontra, maka penulis mencoba mempresentasikan hakekat sumber tasawuf Islam dari visi Islam sendiri. Dari upaya ini diharapkan dapat membersihkan asumsi utopian yang dilancarkan oleh kebanyakan orientalis. Dalam bukunya "Al-Tasawuf al-Islamy", Dr. M. Abdullah Al-Syarqawi telah memberikan empat point pendekatan untuk menguji keaslian tasawuf Islam sebagai produk risalah Islamiah. 
Pendekatan tersebut adalah, pertama, spesialisasi tasawuf sebagai etika dan moral dalam Islam. Pembatasan ini juga telah diketemukan oleh Ibn Qoyim dalam kitabnya "Madarij al-Salikin" yang didukung oleh Al-Kattani dengan statemennya, "Tasawuf Islam adalah etika. Jika etikamu bertambah (bagus), maka bertambahlah kebersihan jiwamu." Seiring dengan zaman yang selalu bergulir, para sufi telah merumuskan etika agama ini menjadi suatu disiplin ilmu yang berdiri sendiri. Disiplin ilmu ini yang mulai berkembang sejak abad III Hijriah dan kita kenal sampai sekarang dengan istilah ilmu Tasawuf Islam. Ilmu ini, menurut pendapat yang mu'tabar, pertama kali dikembangkan oleh Abu Yazid Al-Busthami yang diteruskan oleh muridnya Al-Junaid.

Sosiolog muslim Ibn Khaldun telah menyatakan secara definitif bahwa ilmu tasawuf adalah ilmu syar'i kontemporer dalam agama yang asal-usulnya dari para sahabat, tabiin dan para ulama setelahnya. Sedang menurut DR. Taftazani ilmu tasawuf adalah ilmu syar'i yang awal pembentukan konsepnya bersumber kepada Al-Qur'an dan AlSunnah. Tesis-tesis ini cukup beralasan karena pada dasarnya secara global Risalah Islamiah telah meliputi empat dimensi, yaitu; aqidah, hukum ibadah, hukum mu'amalah, dan etika (akhlak). Bisa dibuktikan bagaimana Rasulullah banyak mengkorelasikan antara keimanan dan etika dalam hadits-haditsnya, misalnya: "Yang paling sempurna keimanan orang-orang mu'min adalah yang paling bagus etika mereka." (Al-Hadits).

Dalam disiplin ilmu tasawuf tersebut, telah dirumuskan konsep tentang merambah jalan Allah (suluk) yang diawali dengan taubat (mujahadah al-nafs), demikian juga konsep "al-ahwal wa al-maqamat".

Pengertian maqam di sini lebih dipersepsikan sebagai posisi antara seorang hamba dihadapan Tuhannya yang diaplikasikan dalam bentuk ibadah, mujahadah dan riyadhah. Bisa dicontohkan maqam di sini seperti; taubat, zuhud, wara', faqir, sabar, ridha, tawakkal dan seterusnya. Sedangkan bentuk-bentuk ahwal adalah seperti; muraaqabah, qurb, mahabbah, khauf, rajaa, syauq, thuma'niinah, musyaahadah, yaqiin dan seterusnya.

Bagi umumnya umat Islam dan kaum sufi khususnya, tidak asing lagi bahwa semua konsep yang ada dalam al-ahwal wa al-maqamat telah 
disandarkan pada Al-Qur'an dan Al-Sunnah. Mereka menyandarkan mujahadah al-nafs dengan QS. Al Ankabut : 69, Al Nazi'at :40-41, Yusuf:53, maqam taqwa dengan QS. Al Hujurat: 13, maqam zuhud dengan QS. Al-nisa:77 dan Al- Hasyr:9, maqam tawakkal dengan QS. Al- Thalaaq:3 dan Al-Taubah:51, maqam syukur dengan QS. Ibrahim:7, maqam shabr dengan QS. Al-Nahl:127 dan Al-Baqarah:100, maqam ridha dengan QS. Al- Maaidah:119, hal mahabbah dengan QS. AlMaaidah:40, maqam ma'rifat dengan QS. Al-Baqarah:282 dan AlKahfi:65, hal khauf dengan QS. Al-Sajdah:16, hal rajaa dengan QS. AlAnkabut:5 dan sebagainya.

Sanggahan Terhadap Teori Orientalis. Teori Goldziher dan Nicholson sebagaimana telah diuraikan di atas, dilihat dari berbagai aspek mengandung banyak kelemahan. Bila mereka mengakui bahwa tasawuf tidak murni dari ajaran Islam, ini dikarenakan titik fokus kesimpulan mereka hanya mengkaji tasawuf dari ajaran-ajaran atau prilaku kehidupan para sufi. Harus di akui, bahwa memang ada pola kesamaan kehidupan dan pemikiran para tokoh sufi dengan ajaran-ajaran di luar Islam, tetapi adanya kesamaan ini bukan berarti mereka mengambil ajaran di luar Islam, sebab al-Qur'an dan al-Hadits adalah sumber utama yang sarat dengan ajaran-ajaran tasawuf. Nampaknya Goldziher dan Nicholson tidak bersungguh-sungguh mengkaji kedua sumber tersebut. Titik fokus mereka tertuju pada pemikiran dan pola hidup para sufi, bukan pada ajaran formal yang menjadi landasan tasawuf, dan mereka pula telah melupakan untuk mengkaji kehidupan Nabi Muhammad SAW dan sahabat-sahabatnya yang menjadi anutan dari para tokoh sufi. Kelemahan lain dari teori mereka, bahwa mereka mengindentikkan ajaran Islam sebagaimana ajaran non Islam yang dibangun dari hasil produk pemikiran. Mereka lupa bahwa Islam adalah agama wahyu yang bukan produk pemikiran manusia. Semua ajaran yang terkadung di dalamnya bersifat universal dan terjamin

kebenarannya serta tidak akan mengalami perubahan. Kepercayaan dan agama Nashrani, Budha, Hindu, dan budaya pemikiran Yunani dan Persia adalah produk pemikiran manusia yang terlepas dari ajaran wahyu. Adanya kesamaan konsep zuhud dan fakir dalam ajaran Nashrani dengan prilaku para sufi yang hidup zuhud dan memfakirkan diri bukan 
berarti para sufi mengambil ajaran Nashrani untuk menjadi pegangan mereka, tetapi hanyalah sekedar adanya kesamaan dari aspek ajaran antara Nashrani dan Islam saja. Hidup zuhud dan fakir sesungguhnya telah dipraktekkan oleh Rasulullah SAW dan para sahabatnya sebelum para tokoh sufi muncul ke permukaan. Rasulullah SAW telah mempraktekkan hidup zuhud, qana'ah, takwa, mahabbah, syukur, taubat, ridha dan tawakkal dalam kehidupannya sehari-hari, begitu pula para sahabatnya. ${ }^{156}$ Kelemahan lain dari teori Goldziher dan Nicholson, adalah terlalu gegabah menyimpulkan bahwa ajaran tasawuf bersumber dari ajaran Hindu-Budha. Konsep fana dan praktek kontemplasi dalam ajaran Hindu-Budha sama sekali tidak ada pengaruhnya dengan praktek ajaran tasawuf oleh para tokoh sufi. Bila dikaji secara historis tidak ada data yang menunjukkan bahwa agama Hindu-Budha berkembang di tanah Arab. Menurut Qomar Kailani, adalah pendapat yang ekstrim sekali kalau mengatakan bahwa ajaran tasawuf berasal dari HinduBudha. Ini berarti pada zaman Nabi Muhammad SAW telah berkembang ajaran Hindu-Budha itu di Makkah dan Madinah, padahal sepanjang sejarah belum ada kesimpulan seperti itu. Demikian pula halnya dengan pengaruh dari Persia, juga belum ditemukan argumentasi yang kuat yang menyatakan bahwa kehidupan rohani Persia telah masuk ke tanah Arab, tetapi yang terjadi justru sebaliknya, bahwa kehidupan rohani Arab yang masuk ke tanah Persia. ${ }^{157}$ Sama juga hal nya dengan pengaruh dari ajaran Neo Platonis Yunani, tidak ada data yang dapat dipercaya bahwa prilaku kehidupan tasawuf Nabi Muhammad SAW dan tokoh sufi awal Islam diwarnai ajaran pemikiran Yunani.

Pengaruh Neo Platonis berkembang jauh setelah ajaran tasawuf dipraktekkan. Penutup Dari uraian di atas dapat disimpulkan bahwa kesimpangsiuran teori asal mula tasawuf sesungguhnya berawal dari keikutsertaan kaum orientalis dalam memahami sumber ajaran Islam. Mereka terlalu cepat menyimpulkan tanpa mengkaji dahulu ajaranajaran tasawuf dalam al-Qur'an dan al-Hadist. Obyek kajian mereka

\footnotetext{
${ }^{156}$ Alwan Khoiri, . . . 36-49

${ }^{157}$ Abuddin Nata, . . . 188
} 
tertuju pada ide dan praktek kehidupan kaum sufi, bukan pada konsep ajaran yang dipegang oleh kaum sufi yang telah mempunyai landasan normatif di dalam al-Qur'an. Jika mereka mencoba memahami alQur'an dan sejarah asal mula praktek tasawuf, maka teori mereka yang mengatakan bahwa ajaran tasawuf dipengaruhi unsur di luar Islam dengan sendirinya gugur dan tertolak secara akademis. Teori yang dapat diterima adalah teori yang mengatakan bahwa ajaran tasawuf murni dari ajaran Islam bukan pengaruh dari luar Islam. Pemikiran dan praktek tasawuf yang dihasilkan dari pemahaman terhadap al-Qur'an dan alHadits berbeda dengan pemikiran bebas yang tidak bersumber dari keduanya. Pemikiran yang tidak bersumber dari al-Qur'an dan al-Hadits bersifat liberal, sehingga tidak dapat dijadikan sebagai rujukan untuk membuat suatu sebuah grand teori yang terpercaya dalam mengkaji asal usul ajaran tasawuf dalam Islam.

\section{KESIMPULAN}

Penutup Dari uraian di atas dapat disimpulkan bahwa kesimpangsiuran teori asal mula tasawuf sesungguhnya berawal dari keikutsertaan kaum orientalis dalam memahami sumber ajaran Islam. Mereka terlalu cepat menyimpulkan tanpa mengkaji dahulu ajaranajaran tasawuf dalam al-Qur'an dan al-Hadist. Obyek kajian mereka tertuju pada ide dan praktek kehidupan kaum sufi, bukan pada konsep ajaran yang dipegang oleh kaum sufi yang telah mempunyai landasan normatif di dalam Al-Qur'an. Jika mereka mencoba memahami AlQur'an dan sejarah asal mula praktek tasawuf, maka teori mereka yang mengatakan bahwa ajaran tasawuf dipengaruhi unsur di luar Islam dengan sendirinya gugur dan tertolak secara akademis. Teori yang dapat diterima adalah teori yang mengatakan bahwa ajaran tasawuf murni dari ajaran Islam bukan pengaruh dari luar Islam. Pemikiran dan praktek tasawuf yang dihasilkan dari pemahaman terhadap Al-Qur'an dan alHadits berbeda dengan pemikiran bebas yang tidak bersumber dari keduanya. Pemikiran yang tidak bersumber dari Al-Qur'an dan al-Hadits bersifat liberal, sehingga tidak dapat dijadikan sebagai rujukan untuk membuat suatu sebuah grand teori yang terpercaya dalam mengkaji asal usul ajaran tasawuf dalam Islam.Tidak disangsikan lagi bahwa segala 
rangkaian kehidupan Rasul yang biasa disebut dengan Al-Sunnah dan para sahabat telah terwarnai dan senada dengan ayat-ayat di atas.Tasawuf merupakan warisan Nabi dalam rangka memberikan petunjuk, membina dan membimbing ruh manusia untuk merambah jalan al-haq.

Seperti yang sudah terungkap di atas bahwa tasawuf adalah merupakan moral agama, maka jelas tasawuf termasuk salah satu dari ketiga tugas besar Rasulullah. Satu di antara tugas besar itu adalah mensucikan dan membimbing ruh untuk merambah jalan al-haq (QS. Al Jum'ah:2). Berangkat dari sini, amat sulit dipungkiri bahwa sumber tasawuf Islam adalah Sunnah Rasul. Dan kita juga tidak mengingkari adanya pengaruh luar yang masuk dalam tasawuf Islam pada masa perkembangannya. Tapi mudah sekali pengaruh-pengaruh tersebut terdeteksi oleh dasar asli tasawuf Islam tersebut.

Keterikatan para syeikh sufi dengan Al-Qur' an dan Al-Sunnah. AlJunaid salah seorang imam sufi yang cukup terkenal mengatakan, "Kita mengetahui hal ini (kon-sep tasawuf) mempunyai hu-bungan erat dengan hadits Nabi". Dan, "Setiap sesuatu yang tidak didasarkan pada Al-Qur'an dan Al-Sunnah, menjadi sesuatu yang batal", kata Syeikh Sahal. Dan masih banyak lagi statemen-statemen para tokoh sufi yang termaktub dalam buku-bukunya.Pengakuan gembong-gembong kaum orientalis sendiri yang banyak menyatakan bahwa Al- Qur'an dan AlSunnah adalah sumber dan sandaran tasawuf Islam. Pengakuan para orientalis secara obyektif tersebut sudah banyak kita dengar di atas. Mereka cenderung membela tasawuf Islam dan membantah asumsi negatif para kaumnya sendiri.

Di antara para orientalis tersebut adalah Arberry, A. Schimmel, Spencer T., dan R. Nicholson, seorang sejahrawan handal dan termasuk pemimpin studi tasawuf di Inggris. Tidak tanggungtanggung mereka semua telah menelorkan buku yang spesifik mengkaji tentang tasawuf Islam. Satu sampel, R. Nicholson telah mengeluarkan empat buku kajian tasawufnya yaitu, "Selected Poems From Diwan al-Shams, Studies in Islamic Mysticism, The Mystics of Islam, dan The Idea of Personality in Sufism." 
Massignon, seorang pemimpin studi tasawuf di Perancis telah mengkonklusikan bahwa sumber tasawuf Islam adalah: Pertama, AlQur'an (sumber paling esensial). Kedua, Ilmu-ilmu Arab keislaman (seperti: Hadits, fiqh dan nahwu). Dan ketiga, bahasa ilmiah yang berkembang di timur pada abad VI pertama (seperti bahasa Persi dan Yunani). Di samping Massignon, Wiliam Stoddart juga seorang orientalis telah menghina rekan-rekannya yang telah mengkaji Islam tanpa menelusuri jejak sumber Islam. Ia mengistilahkan sebagai kerja ilmiah yang sia-sia (nonsen). Bagaimana mungkin bisa menggambarkan kehidupan manusia tanpa jasad manusia. Dan tidak mungkin dikatakan tasawuf Islam kalau bukan Islam, dan seterusnya. Yang jelas, ia telah mengkonklusikan bahwa tasawuf Islam tetap Islamiah dan sunniah secara murni dan konsekuen. Epilog Dari kajian di atas, kita bisa merasakan betapa orisinalitas tasawuf telah teruji oleh kajian ilmiah yang digelar oleh kaum orientalis. Mereka yang jauh dari ruh-ruh Islam ternyata banyak yang tak sanggup untuk menyembunyikan kekaguman mereka terhadap tasawuf Islam. Sehinga mereka yang sengaja menjebak umat Islam dengan memberikan rasa skeptis terhadap tasawuf Islam, telah disibukkan oleh serangan balik yang tidak kalah sengitnya dari kaum mereka sendiri.

Dengan mengamati kajian di atas pula, penulis setuju de-ngan konklusi DR. M. Abdullah Al-Syarqawi, bahwa sebenarnya orientalis yang mbalelo tersebut adalah mereka yang mengkaji secara ilmiah di abad XIX. Sedangkan dalam kajian para orientalis terhadap tasawuf sejak abad XX, mulai terasa adanya upaya reinterpretasi dan repersepsi terhadap asumsi utopian pendahulu mereka. Dan perlahan tapi pasti, statemen-statemen para orientalis yang mbalelo tersebut, kini mulai dimakan rayap dan mulai mengalami pembusukan. Wallahu A'lam. 


\section{DAFTAR PUSTAKA}

Abul Alaa Afify, Tasawuf Islam Dan Terjemahnya, Iskandariyah:Lajnah Al-Ta'lif,tt.

Abul Qasim Abdul Karim Hawazin Al-Qusyairi an-Naisaburi, Risalah AL-Qusyairiyah, Jakarta: Pustaka Amani, 2007.

Abdul Qodir Isa, Hakikat Tasawuf, ttp:Penerbit Qisthi Press, 2011.

Abdul kadir riyadi, antropologi tasawuf Jakarta: LP3ES, anggota Ikapi, 2014.

Abu al-Alaa "Afify, $F i$ al Tashawwuf al Islam wa Tarikhihi, Iskandariyah: Lajnah al Ta'lif wa al-Tarjamah wa al Nasyr, tt.

Abuddin Nata, Akhlak Tasawuf, Jakarta: PT.Raja Grafindo Persada, 2009.

Abul al-Wafa' al-Ghanimi al-Taftazani, Madkhal ala al Tashawwuf alIslam, terj. Ahmad Rofi' Ustman, “Sufi Dari Zaman ke Zaman", Bandung: Pustaka:1985.

Amin al-Kurdi, Tanwir al-Qulub fi Mu'amalah 'Alam al-Ghuyub, Surabaya: Bungkul Indah, tt.

Fudoli zaini, sepintas sastra sufi: tokoh dan pemikirannya Surabaya:risalah gusti, 2000.

Gholab, Muhammad. Tasawuf Al Muqorin, Mesir: Maktabah AlNahdhah.tt. 
Ghazali (al), Ihya' 'Ulum ad-Din, Semarang: Maktabah Usaha Keluarga, tt. Alwan Khoiri,et al, Akhlak/Tasawuf, Yogyakarta: Pokja Akademik UIN Sunan Kalijaga, 2005.

Harun Nasution, Falsafat Dan Mistisme Dalam Islam,Jakarta: Bulan Bintang, 1973.

Hamka, Renungan Tasawuf. Jakarta: pustaka panjimas,1986.

Ibn Mahalli Abdullah Umar, Perjalanan Rohani Kaum Sufi,Yogjakarta: Kresi Wacana, 2000.

Ignas Goldziher, Pengantar Teologi dan Hukum Islam Jakarta: INIS Jakarta, 1991.

Khalifah, Kasyf Al-Zhunun Asami, ttp: Al-Kutub Wa Al-Funun,tt.

Kartanegara, Mulyadi. Menyelami Lubuk Tasawuf, Jakarta: penerbit Erlangga,2006.

Kurdi (al), Muhammad Amin Tanwir Al-Qulub Fi Muamalah 'Alam AlGhuyub, (Surabaya: Pen Bungkul Indah, tt.), 406.

M. Jamil, Akhlak Tasawuf, Ciputat: Referensi, 2013.

Moh. Ghallab, al-Tasawuf al-Muqarin, Kairo: Maktabah al-Nahdah, t.t.

Nawawi, Muhammad Amin Al- Ta'aruf Li Madzhabahli Tasawuf, Kairo:Maktabah Al-Kuliyah Al-Azhariyah.1969.

Nurcholis Madjid,Islam Doktrin Dan Peradaban, Jakarta: Paramadina, 2000.

Qusyairi (al), Al-Risalah Al-Qusyairiyyah, Mesir: Musthofa Al-Bab AlHalabi, 1959. 
Reynold Nicholson, The Mystics of Islam, terj. A. Nashir Budiman, "Tasawuf Menguak Cinta Ilahi” Jakarta: Raja Grafindo, 1993.

Reynold Nicholson, Jalaluddin Rumi, Ajaran dan Pengalaman Sufi Jakarta: Pustaka Firdaus, 1993.

Rosihun Anwar, Akhlak Tasawuf, Bandung: CV Pustaka Setia, 2010.

Sholikhin, Muhammad, Tradisi Sufi dari Nabi, Cakrawala: Yogyakarta, 2009.

Syarqawi (al), Muhammad Abdullah. Sufisme \& Akal, terj. Halid alKaf Bandung: Pustaka Hidayah, 2003.

Suhrawardi (a), Awarif al_Ma,rif Kamisy Ihya' 'Ulum al-Din, Singapura: Mar'I,tt.

Syamsun Ni'am, Tasawuf Studies, Yogjakarta: Ar Ruzz Media, 2014.

Syamsul arifin, et al,. spritualitas islam dan peradaban masa depan Yogyakarta:sipress, 1986.

Tim penyusun MKD, Akhlak tasawuf, Surabaya:iain sa press, 2011.

Yasir Nasution, Cakrawala Tasawuf Jakarta: Putra Grafika, 2007. 